\title{
River Bank Analysis in the Vicinity of Sebatik Island and Its Influence to Determine Boundary of Indonesia-Malaysia
}

\author{
Ardiawan Jati ${ }^{1 *}$, Danar Guruh Pratomo ${ }^{1}$ \\ ${ }^{1}$ Departemen Teknik Geomatika, Institut Teknologi Sepuluh Nopember, Surabaya, Indonesia \\ Email : *ardiawan.jati@gmail.com,dg.pratomo@gmail.com
}

Dikirim : 28 Juni 2020

Diterima: 28 September 2020

\begin{abstract}
Sungai sebagai batas tercantum dalam Perjanjian Belanda-Inggris tahun 1915 dengan Peta Lampiran tanpa koordinat yang jelas. Ini merupakan kendala dalam melacak batas-batas di sungai karena yang mana sungai itu dinamis, perubahan bentuk dan tepi sungai dapat terjadi dalam kurun waktu lebih dari 100 tahun. Citra satelit Landsat multi-temporal yang diproses dengan kombinasi band (color composite) digunakan untuk mengamati posisi tepi sungai dari tahun 1989 hingga 2019 dengan interpretasi visual dan digitalisasi manual. Hasilnya, selama 30 tahun terjadi pergeseran di tepi sungai Sikapal dengan rata-rata 11,4 m di sisi kanan (Indonesia) dan $15 \mathrm{~m}$ di sisi kiri (Malaysia). Pergeseran rata-rata tepi sungai Tamboe adalah sisi kanan $25,1 \mathrm{~m}$ dan di sisi kiri 8,8 $\mathrm{m}$. Pergeseran ini relatif kecil karena di sekitar sungai Sikapal dan Tamboe banyak ditumbuhi oleh hutan bakau yang dapat memperlambat laju erosi. Tepi sungai pada tahun 1989, 1999, 2009 dan 2019 digunakan sebagai dasar penentuan batas Indonesia-Malaysia menggunakan pendekatan tiga tahap. Hasilnya, ada perbedaan dalam bentuk garis batas meskipun kecil. Namun, wilayah sungai Indonesia dan Malaysia masih memiliki rasio proporsional 1: 1,03 pada tahun 1989, 1999, 2009 dan 2019. Meskipun rasio tersebut sama, luas sungai telah meningkat sebesar $0,08-0,11 \mathrm{~km}^{2}$.
\end{abstract}

Keywords: Indonesia-Malaysia Boundary, 1915 Netherland-British Agreement, River bank, Border Line, Spatial Data

\begin{abstract}
Abstrak: River as the boundary is listed in the 1915 Netherland-British Agreement with its Annex Map without any clear coordinates. This is an obstacle in tracing boundaries in the real river because where river is dynamic, changes in the river shape and river bank can occur in more than 100 years. Multitemporal Landsat satellite imagery processed with a combination of bands (color composite) is used to observe the position of the river bank from 1989 to 2019 with visual interpretation and manual digitization. As a result, over 30 years there was a shift in the Sikapal river bank with an average of 11.4 $\mathrm{m}$ on the right side (Indonesia) and $15 \mathrm{~m}$ on the left side (Malaysia). The average shift of the Tamboe river bank is the right side $25.1 \mathrm{~m}$ and on the left side $8.8 \mathrm{~m}$. The shift is relatively small because around the Sikapal and Tamboe rivers banks are overgrown by mangrove forests which can slow down the rate of erosion. River banks in 1989, 1999, 2009 and 2019 were used as a basis for delimitation of the Indonesia-Malaysia boundary using a three-stage approach. As a result, there are differences in the shape of the boundary line although it is small. However, the river area of Indonesia and Malaysia still has a proportional ratio of 1: 1.03 in 1989, 1999, 2009 and 2019. Although the ratio is the same, the area of the river has increased by $0.08-0.11 \mathrm{~km}^{2}$.
\end{abstract}

Kata kunci: Batas Indonesia-Malaysia, Perjanjian Belanda-Inggris tahun 1915, Tepi Sungai, Garis Batas, Data Spasial

\section{Introduction}

The river is a drainage channel that is formed naturally. The existence of flowing water causes river bank to be eroded throughout its existence Sosrodarsono (1983). River is one of the natural features that is commonly used as a border. Tamboe River and Sikapal River in Nunukan and Tawau regions are the borders of Indonesia and Malaysia. Even though it's a 
river, it's a land boundary, not a maritime boundary. The evidence which states that it is the boundary of Indonesia and Malaysia is The Boundary Agreement between Netherlands and British signed in London, September 28, 1915.

The Indonesian and Malaysian Land Boundaries have not yet been fully completed, although basically Indonesia and Malaysia agreed to follow principle of utis posidetis juris which means border is inherited from the colonial Jones (1945). The agreement explains description of the boundary between Netherlands and British from West Pillar on Sebatik Island to Bukit Sikapal (AA2 Pillar). The agreement is accompanied by an annex map but information of datum and coordinate system used and list of coordinates of the border are not written.

Datum information, coordinate system and list of boundary coordinates that are not written become obstacles in redrawing the boundaries on the current map. Actually the description of boundary in the agreement can be used as a reference to redraw border line, but there is no guarantee that river between West Pillar to AA2 Pillar is still exactly same condition when the Netherland-British agreement was made.

River change can affect shape of border line. It has been more than 100 years since the agreement was made until now. River is very likely to change due to the effects of erosion. Erosion is a form of soil damage as a result of loss of topsoil layers (Arsyad, 2006). Erosion is definitely possible and zero erosion is not possible (Frevert, et. al., 1950). River bank monitoring can be done with digital imagery. Digital imagery is a picture of the earth surface as seen from space (satellite) or from the air (airplanes) (Prahasta, 2008).

Another research on river bank change due to erosion has been conducted in the southern Mekong River. It used optical satellite imagery to observe changes in river banks from 1973 to 2008. River banks of Mekong were eroded along the left and right. The erosion phenomenon occurs strongly in Sa Dec District at a rate of 33m per year (Ngyuyen, 2010). Likewise research conducted in Manu River, Bangladesh for a period of thirteen years (19972010). Using Landsat satellite imagery, they get very high river bank shifts on the left and right respectively 656m and 628m (Dabojani, Mithun, dan Kanti, 2013).

In line with previous research, this research aims to monitor river shape and river bank in spatial terms with multi-temporal satellite imagery data for 30 years to obtain results of a river shapes and river bank comparison. River bank for 30 years was used to draw IndonesiaMalaysia border line. Analysis of 30-year difference in border line is the final product of this study.

\section{Data and Location}

The data used are 1915 Netherland-British Agreement regarding boundary of British (in Malaysia) and Netherland (in Indonesia) and Annex Maps with a scale of 1: 250,000, Topography Map with a scale of 1: 50,000, Nautical Chart (Mening Island to Ligitan Island) with a scale of 1:200,000 and multi-temporal landsat satellite imagery in 1989, 1999, 2009 and 2019 , detail are shown in table 1.

Table 1. List of Remote Sensing Data

\begin{tabular}{cccc}
\hline No. & Area & Date & Satellite \\
\hline 1 & Nunukan - Tawau & 21 Sept 1989 & Landsat 5 TM \\
2 & Nunukan - Tawau & 30 Dec 1999 & Landsat 7 ETM \\
3 & Nunukan - Tawau & 30 Oct 2009 & Landsat 5 TM \\
4 & Nunukan - Tawau & 29 Dec 2019 & Landsat 8 OLI \\
\hline
\end{tabular}

Scope of area focuses on rivers and waters west of Sebatik Island to AA2 pillars along $20.6 \mathrm{~km}$ which are divided into $9.6 \mathrm{~km}$ of rivers with $120-500$ meters width and $11 \mathrm{~km}$ of water 
with widths reaching $3 \mathrm{~km}$. The location is border of Indonesia in Nunukan, North Kalimantan with Malaysia in Tawau, Sabah. The location is shown in Figure 1.

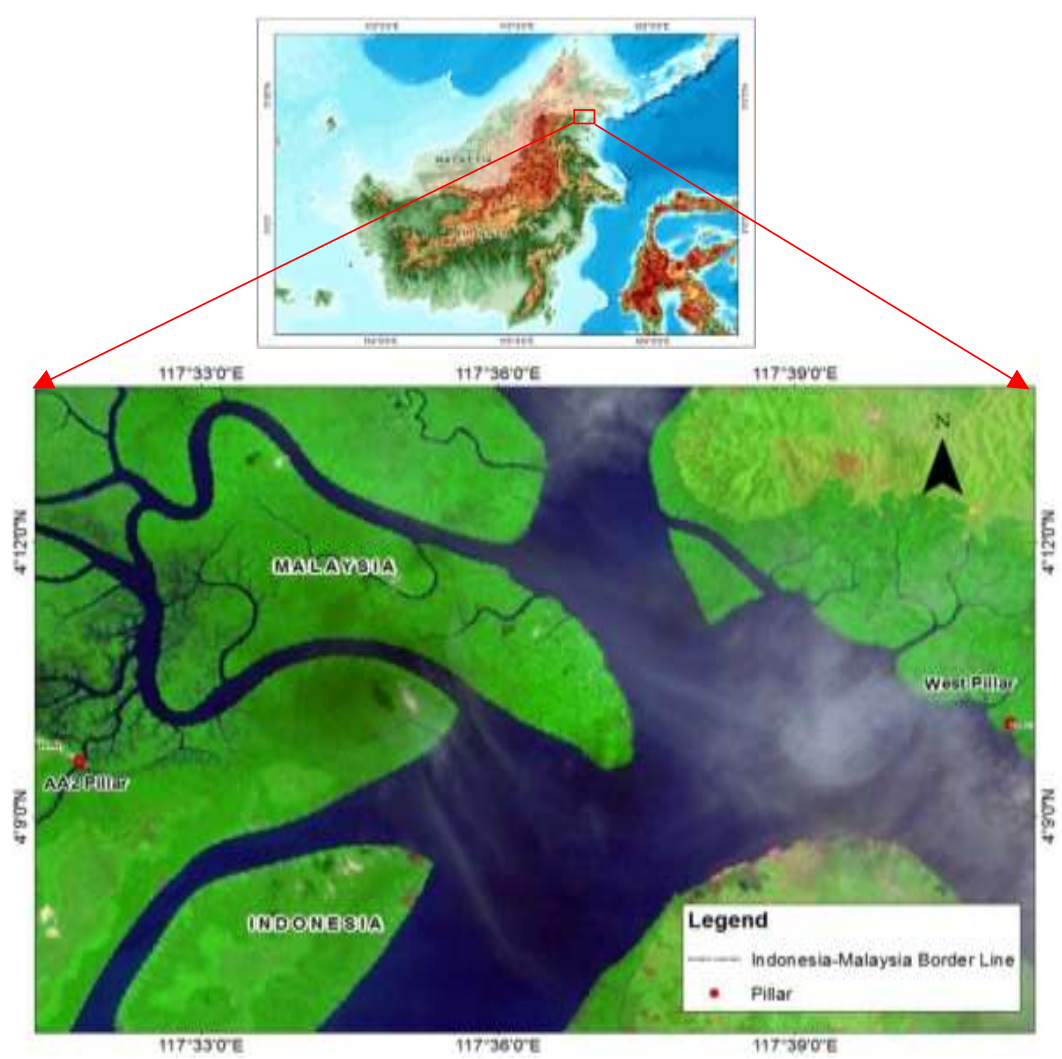

Figure 1. Border Area: Nunukan (Indonesia) - Tawau (Malaysia)

\section{Methods}

This research requires several steps, starting from data compilation, datum and coordinate system transformation, geometric correction, digitizing until border line delimitation. Data Processing Flow Chart is shown in figure 2.

Landsat satellite imagery has WGS84 datum and geographic coordinate system, topographic map has DGN95 datum and UTM projection coordinate system, Nautical Chart has WGS84 datum and mercator projection coordinate system, whereas Annex Map of 1915 Netherland-British Agreement has Bessel 1841 datum and astronomical coordinate system. All data is transformed into same datum and coordinate system, namely WGS84 datum and UTM Projection coordinate system with GIS software. 


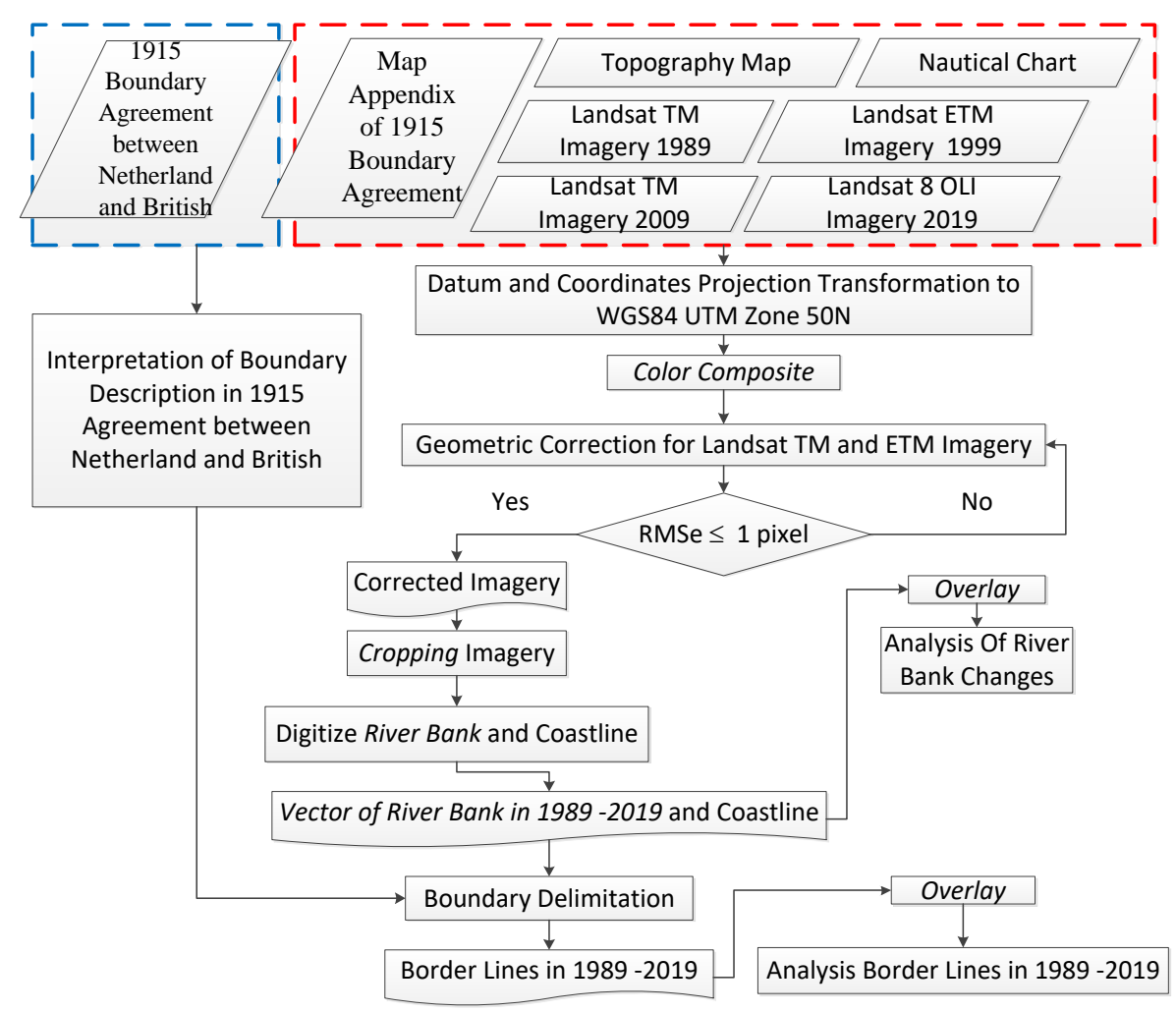

Figure 2. Data Processing Flow Chart

Transformation from Bessel 1841 datum and astronomical coordinates to WGS84 datum and UTM projections coordinates are done by calculating vertical deflection component. Global Geoid models are used for calculation of the vertical deflection component is the Earth Gravitational Model (EGM) in 2008 with components obtained from the NASA / GSFC site (2014) (Hadi, Abidin, dan Priyatna, 2015). There are four tie points used to register map in WGS 84, UTM projection which is shown with its vertical deflection in table 2.

Colour composite aims to combine bands in satellite imagery to produce certain colours that make it easy to identify objects, river banks in this case. A suitable colour composite used to distinguish land and water is combination of band 7, band 4 and band 2 for red, green and blue (RGB) that apply to Landsat TM imagery in 1989, 2009 and Landsat ETM imagery in 1999. Whereas Landsat 8 OLI 2019 applies combination of RGB is band 7, band 5 and band 3 .

Geometric correction is done on Landsat TM and ETM satellite imagery which refers to position of object in Landsat 8 OLI. Geometric correction aims to register satellite imagery by placing the pixel position on the satellite imagery based on the base map so that the position of the objects in the satellite image matches with actual position in the field. Method often used is Root Mean Square Error (RMSE) where the tolerance is $\leq 1$ pixel (Sukojo, 2012).

$$
R M S E=\left(\sum_{i=1}^{i-n}\left(x_{i}-x_{i}^{\prime}\right)^{2} / n\right)^{1 / 2}
$$

where ${ }^{x_{i}}$ is the observed value, ${ }^{x_{i}}$ is the modelled value, and $n$ is the number of elements.

Cropping satellite imagery is done to focus area of interest and reduce data size. Digitizing river banks is carried out on landsat imagery in 1989, 1999, 2009 and 2019 by first interpreting imagery then identifying objects manually (Lillesand, Kiefer, dan Chipman, 2004).

Digitization of coastline is carried out on Nautical Chart by observing aspect of accuracy with the rule that digitization is done at twice zooming of map scale that be produced 
(Badan Informasi Geospasial, 2016). Digitization of river banks and coastlines is also carried out on an Annex Map of 1915 Netherland-British Agreement. The results of digitization are vector formats. Overlay vector river bank in 1915, 1989, 1999, 2009 and 2019, whether there were changes and how big the changes are. Next, analyze the results.

In another stage, interpretation of boundary descriptions in 1915 Netherland-British Agreement to be depicted on satellite imagery. There are two boundary segments from West Pillar to the AA2 Pillar shown in figure 3. Segment one is from West Pillar to the mouth of Tamboe River. Segment two starts from the mouth of Tamboe River to watershed Bukit Sikapal (AA2 Pillar).

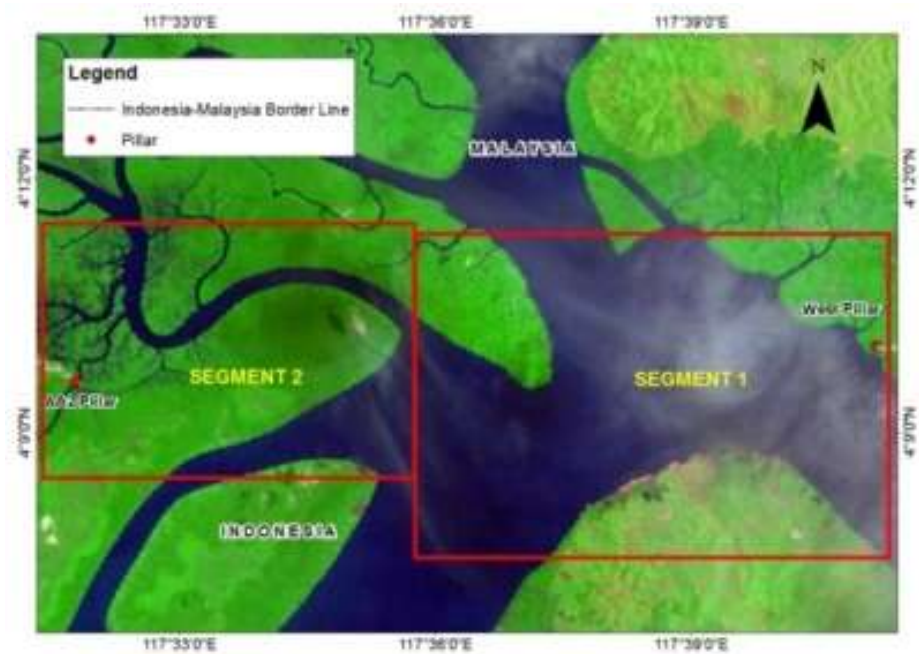

Figure 3. Segment of Boundary

Delimitation of boundary is done by three stage approach method (International Court of Justice. 2009), which is first to construct median line. To get a Median line, it is determined using the equidistance line method. Equidistance line is obtained from the circle which is drawn in contact with river bank or coastline of two countries where the principle of the circle is to have the same length of radius from the outermost to the centre of circle (Arsana, 2007). Second, by considering relevant circumstances. Relevant circumstances are islands and coastlines. Third is the disproportionality test. Disproportionality test is done by comparing length of coastline and area obtained between two countries to get coastline and area that is relevant for both countries. Indonesia-Malaysia border line is drawn on satellite imagery in 1989, 1999, 2009 and 2019 which incidentally has different river banks so that different border lines are also generated. Border lines are compared and then analyzed. 
Table 2. Results of Coordinates Transformation of the 1915 Netherland-British Agreement Map

\begin{tabular}{|c|c|c|c|c|c|c|c|c|c|c|c|c|c|c|c|c|}
\hline \multirow{3}{*}{$\begin{array}{l}\mathbf{N} \\
\mathbf{o .}\end{array}$} & \multicolumn{6}{|c|}{$\begin{array}{c}\text { Astronomis Coordinates, Bessel } \\
1841 \text { Datum } \\
\end{array}$} & \multicolumn{2}{|c|}{$\begin{array}{c}\text { Vertical } \\
\text { Deflection }\end{array}$} & \multicolumn{8}{|c|}{ WGS84 Datum } \\
\hline & \multicolumn{3}{|c|}{$\Phi$} & \multicolumn{3}{|c|}{$\Lambda$} & \multirow[b]{2}{*}{$\eta$} & \multirow{2}{*}{$\xi$} & \multicolumn{3}{|c|}{$\varphi$} & \multicolumn{3}{|c|}{$\lambda$} & \multirow{2}{*}{$\begin{array}{l}\mathrm{N} \\
\mathrm{m}\end{array}$} & \multirow{2}{*}{$\begin{array}{c}\mathrm{E} \\
\mathrm{m}\end{array}$} \\
\hline & $\circ$ & ' & $"$ & $\circ$ & ' & $"$ & & & $\circ$ & ' & $"$ & $\circ$ & ' & $"$ & & \\
\hline 1 & 4 & 40 & 0 & 115 & 40 & 0 & $\begin{array}{c}2.59 \\
8\end{array}$ & $\begin{array}{c}13.8 \\
52\end{array}$ & 4 & $\begin{array}{l}4 \\
0\end{array}$ & $\begin{array}{c}5.9 \\
8\end{array}$ & $\begin{array}{l}1 \\
1 \\
5\end{array}$ & $\begin{array}{l}4 \\
0\end{array}$ & $\begin{array}{l}13 . \\
85\end{array}$ & $\begin{array}{c}51686 \\
4.77\end{array}$ & $\begin{array}{c}35247 \\
1.90\end{array}$ \\
\hline 2 & 3 & 40 & 0 & 115 & 40 & 0 & $\begin{array}{c}- \\
6.98 \\
6\end{array}$ & $\begin{array}{c}- \\
2.37 \\
5\end{array}$ & 3 & $\begin{array}{l}3 \\
9\end{array}$ & $\begin{array}{l}43 . \\
89\end{array}$ & $\begin{array}{l}1 \\
1 \\
5\end{array}$ & $\begin{array}{l}3 \\
9\end{array}$ & $\begin{array}{l}57 . \\
62\end{array}$ & $\begin{array}{c}40553 \\
8.55\end{array}$ & $\begin{array}{c}35172 \\
9.82\end{array}$ \\
\hline 3 & 3 & 40 & 0 & 118 & 0 & 0 & $\begin{array}{c}- \\
4.89 \\
4\end{array}$ & $\begin{array}{c}- \\
1.18 \\
1\end{array}$ & 3 & $\begin{array}{l}3 \\
9\end{array}$ & $\begin{array}{l}49 . \\
59\end{array}$ & $\begin{array}{l}1 \\
1 \\
7\end{array}$ & $\begin{array}{l}5 \\
9\end{array}$ & $\begin{array}{l}58 . \\
81\end{array}$ & $\begin{array}{c}40564 \\
9.32\end{array}$ & $\begin{array}{c}61090 \\
5.19\end{array}$ \\
\hline 4 & 4 & 40 & 0 & 118 & 0 & 0 & $\begin{array}{c}2.92 \\
8\end{array}$ & $\begin{array}{c}2.12 \\
1\end{array}$ & 4 & $\begin{array}{l}3 \\
9\end{array}$ & $\begin{array}{l}53 . \\
77\end{array}$ & $\begin{array}{l}1 \\
1 \\
8\end{array}$ & 0 & $\begin{array}{c}2.1 \\
2\end{array}$ & $\begin{array}{c}51632 \\
8.18\end{array}$ & $\begin{array}{c}61086 \\
8.25\end{array}$ \\
\hline
\end{tabular}

\section{Results and Discussion}

\section{Geometric Correction}

The results of geometric corrections on Landsat satellite imagery in 1989, 1999 and 2009 with 8 control points that spread on the image scene (figure 4) respectively were 0.82 , 0.61 , and 0.84 .

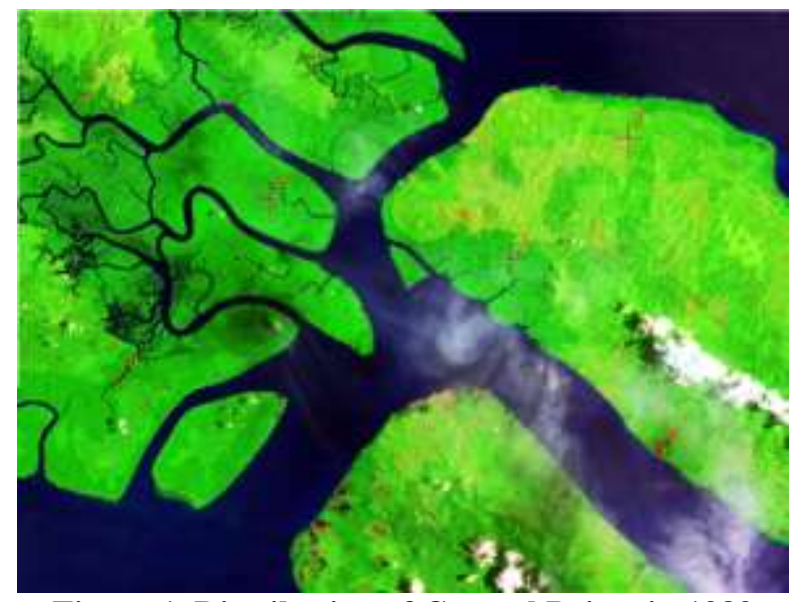

Figure 1. Distribution of Control Points in 1989

Based on the results, it can be concluded that Landsat Satellite Imagery in 1989, 1999 and 2009 have geometric accuracy with RMSe less than equal to one pixel.

\section{Riverbank Monitoring}

The results of river bank monitoring for 30 years from 1989 to 2019 which were divided into two areas, namely Tamboe River and Sikapal River, showed that differences in river banks from 1989 to 2019 were hardly visible visually (scale dependent). That means trend of changes in river banks from 1989 to 2019 is quite small.

In this research several samples were taken along Tamboe River and Sikapal River to get data of the river bank shift in left and right shown in figure 5. The value of river bank shift is shown in table 3 with the statistics in table 4 . The value of the shift is expressed in graphic on the figure 6. 


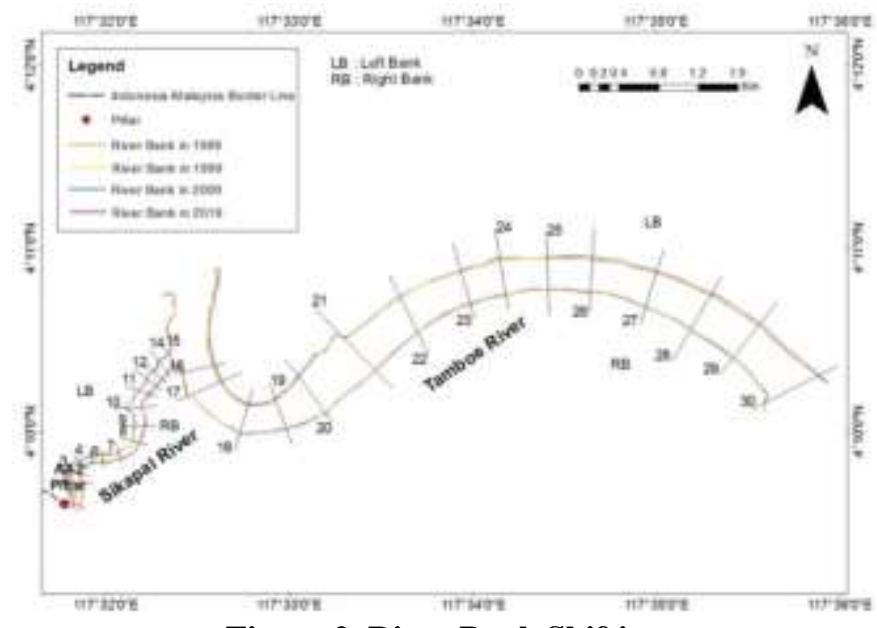

Figure 2. River Bank Shifting

Table 3. River Bank Shifting from 1989-2019

\begin{tabular}{|c|c|c|c|c|}
\hline No. & Left Bank Shift (m) & Direction & Right Bank Shift (m) & Direction \\
\hline 1 & 8.9 & left & 17.2 & right \\
\hline 2 & 17.7 & left & 22.8 & right \\
\hline 3 & 26.8 & left & 17.6 & right \\
\hline 4 & 19.8 & left & 15 & right \\
\hline 5 & 8.7 & left & 4.4 & right \\
\hline 6 & 10.6 & left & 8.6 & right \\
\hline 7 & 8 & left & 10.3 & right \\
\hline 8 & 12.7 & left & 8.7 & right \\
\hline 9 & 6.2 & left & 9 & right \\
\hline 10 & 17.8 & left & 7.2 & right \\
\hline 11 & 23.4 & left & 8 & right \\
\hline 12 & 17.3 & left & 14.5 & right \\
\hline 13 & 17.1 & left & 9.5 & right \\
\hline 14 & 16.7 & left & 7 & right \\
\hline 15 & 13.3 & left & 10.4 & right \\
\hline 16 & 12.4 & left & 29.2 & right \\
\hline 17 & 10.5 & left & 29.6 & right \\
\hline 18 & 4.7 & left & 26.3 & right \\
\hline 19 & 6.5 & left & 24.2 & right \\
\hline 20 & 6.8 & left & 21.1 & right \\
\hline 21 & 7.2 & left & 22.3 & right \\
\hline 22 & 11.9 & left & 17.6 & right \\
\hline 23 & 13 & left & 19.3 & right \\
\hline 24 & 8.3 & left & 25.9 & right \\
\hline 25 & 4.1 & left & 17.1 & right \\
\hline 26 & 10.4 & left & 35.5 & right \\
\hline 27 & 9.3 & left & 26.2 & right \\
\hline 28 & 8.5 & left & 27.7 & right \\
\hline 29 & 9.6 & left & 27.4 & right \\
\hline 30 & 8.5 & left & 27 & right \\
\hline
\end{tabular}


Table 4. Statistic of River Bank Shifting from 1989-2019

\begin{tabular}{ccccc}
\hline \multirow{2}{*}{ Remark } & \multicolumn{2}{c}{ Sikapal River } & \multicolumn{2}{c}{ Tamboe River } \\
\cline { 2 - 5 } & Left & Right & Left & Right \\
\hline Number of samples & 15 & 15 & 15 & 15 \\
Min. shifting & $6.2 \mathrm{~m}$ & $4.4 \mathrm{~m}$ & $4.1 \mathrm{~m}$ & $17.1 \mathrm{~m}$ \\
Max. shifting & $26.8 \mathrm{~m}$ & $22.8 \mathrm{~m}$ & $13 \mathrm{~m}$ & $35.5 \mathrm{~m}$ \\
Average Shifting along River & $15 \mathrm{~m}$ & $11.4 \mathrm{~m}$ & $8.8 \mathrm{~m}$ & $25.1 \mathrm{~m}$ \\
\hline
\end{tabular}

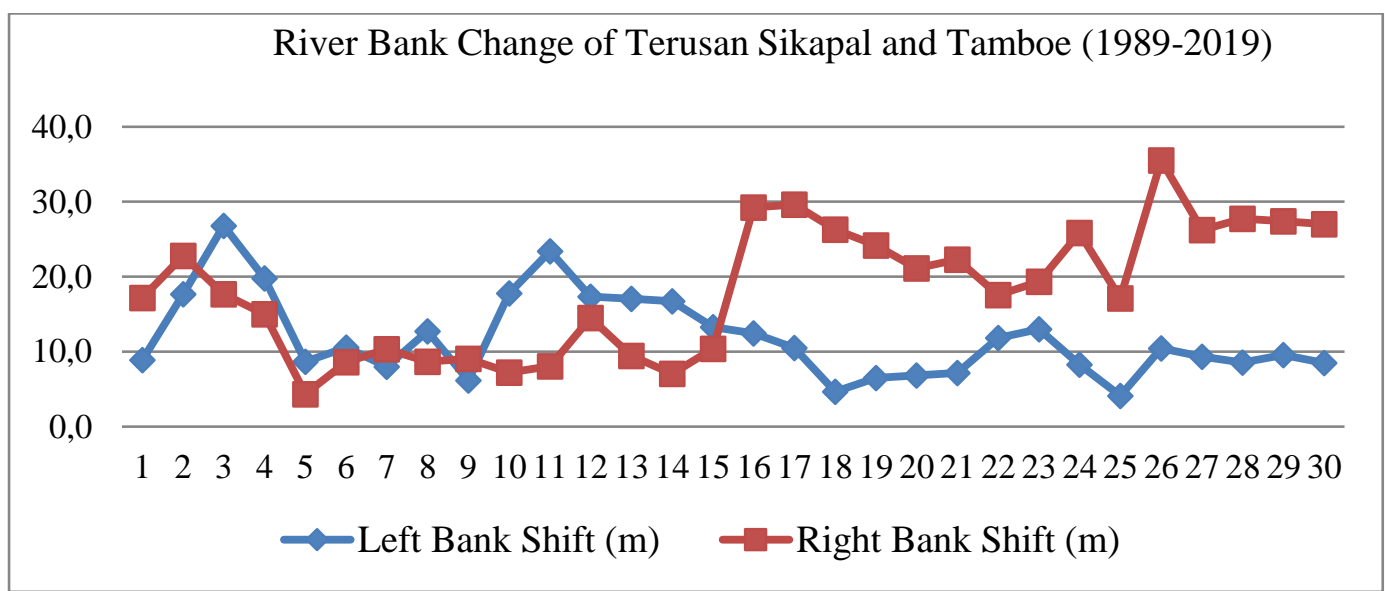

Figure 3. Graphic of River Bank Shifting from 1989-2019

Based on table 3, it can be determined that shifting of river banks of Tamboe and Sikapal rivers each year. Shifting average of river bank each year along Sikapal River is $0.5 \mathrm{~m}$ on the left side and $0.38 \mathrm{~m}$ on the right side. Whereas along Tamboe River, shifting average of river bank each year by $0.29 \mathrm{~m}$ on the left side and $0.84 \mathrm{~m}$ on the right side. Shifting of river banks are generally affected by erosion.

Maximum shifting of the river bank annually is also calculated for the Sikapal River by $0.89 \mathrm{~m}$ on the left side and $0.76 \mathrm{~m}$ on the right side. Whereas along Sikapal River, maximum river bank shifting each year is $0.43 \mathrm{~m}$ on the left side and $1.18 \mathrm{~m}$ on the right side. Maximum shifting is in the river curvature which is an erosion-prone area due to the strong influence of water discharge which has a direct impact on the river curvature (Aher, 2012).

From description above, it can be concluded that river bank change in Tamboe River and Sikapal River over the 30 year observation period is small. Some factors that influence this are:

1. River. Mangroves resist abrasion by seawater and rivers where several locations of mangroves are shown in figure 7.

2. Although for 30 years there have been some changes in forest into agricultural around the Tamboe River but the distance from the river is quite far about 80-100 meters so that mangroves around the river still exist.

3. Gradient / slope of Tamboe and Sikapal rivers are high so the erosion level is low. 

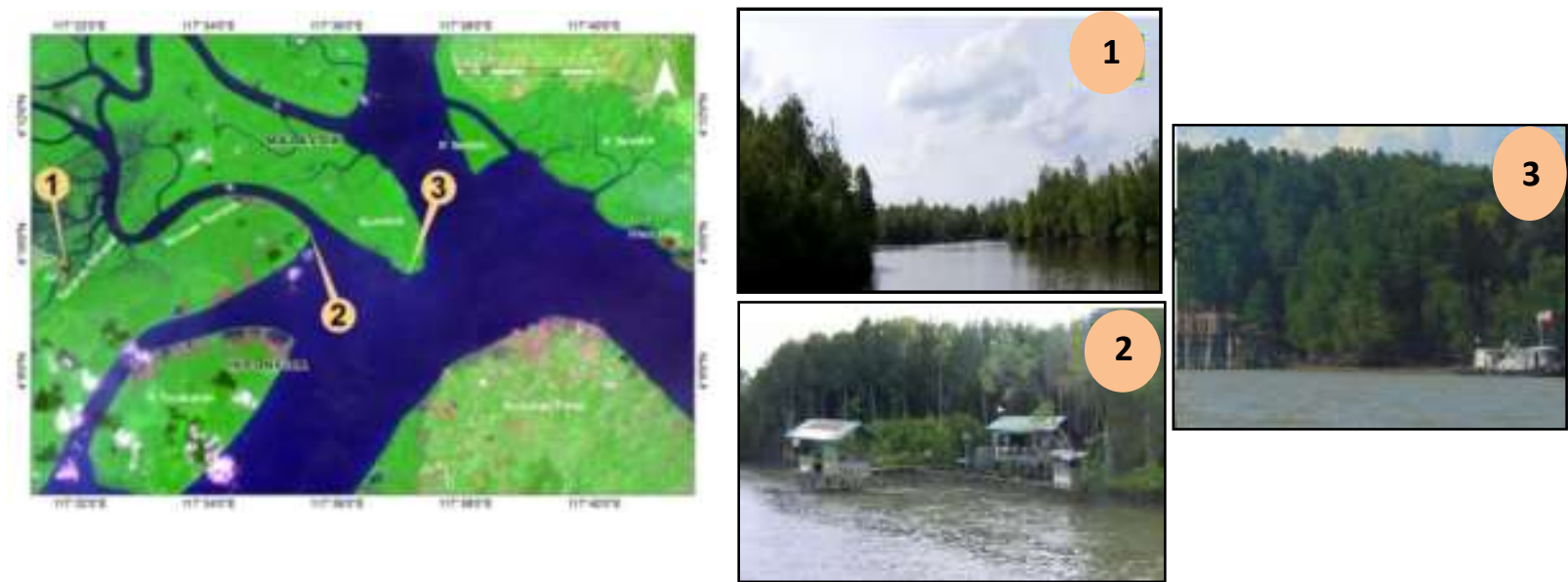

Figure 4. Mangroves Around the River (Nurdin, 2015)

\section{Analysis of River Bank on Annex Map of the 1915 Netherland-British Agreement}

From overlay results in figure 8 , it can be seen that general form of rivers and coastlines in the Annex Map of the 1915 Netherland-British Agreement almost the same to general shape of rivers and coastlines on satellite imagery and Nautical Chart. However, the position of object is not accurate (shown in table 5). In addition, Sikapal River is not described in detail on the agreement map.
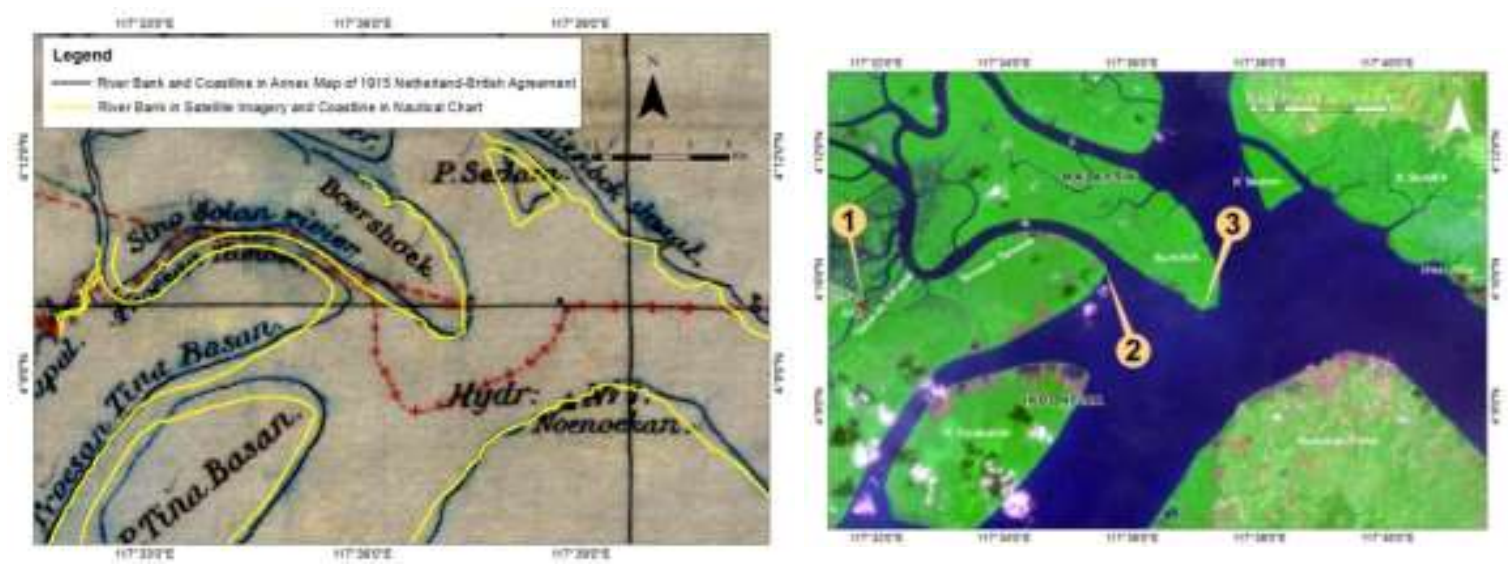

Figure 5. River Bank and Coastline Overlay of the 1915 Netherland-British Agreement with Landsat Imagery and Nautical Chart

The difference in position is not caused by significant change of river, but is caused by:

1. The map of Netherland-British Agreement 28 September 1915 is a small scale map that is 1: 250,000 which $1 \mathrm{~mm}$ error on the map is equal to 250 meters in the field.

2. The map of Netherland-British Agreement 28 September 1915 was made with low accuracy because of the technology at the time.

3. The registration process is not perfect because tie points are limited to four points. 
Table 5. Differences in Position of the Objects on Annex Map of the 1915 Netherland-British Agreement with Satellite Imagery and Nautical Chart

\begin{tabular}{|c|c|c|}
\hline No. & Object & Difference in position (m) \\
\hline 1 & Estuary End of Tamboe River & 491 \\
\hline 2 & North End of Tinabasan Island & 448 \\
\hline 3 & South End of Sedam Island & 456 \\
\hline 4 & Estuary End of Sikapal River & 384 \\
\hline 5 & North of Nunukan Island & 226 \\
\hline 6 & West End of Sebatik Island & 498 \\
\hline
\end{tabular}

From table 5, it can be concluded that river banks and coastlines on t Annex Map of the 1915 Netherland-British Agreement cannot be used as a base map for delimiting boundaries because position of river banks and coastlines is very different both when compared with satellite imagery and Nautical Chart.

\section{Border Line Delimitation}

\section{Constructing equidistance line}

For segment 1, basic data used is the coastline that has been digitized from the Nautical Chart. Starting from the boundary pillar on the west coast of the island of Sebatik, the boundary follows the parallel of 4010' north latitude westward until it reaches the middle of the river, thence keeping a mid-channel course until reaches the middle of the mouth of Tamboe River. West Pillar which has been repositioned in parallel 4010 ' Geographical North Latitude with WGS 84 datum (Badan Informasi Geospasial, 2019). The border lines and construction are shown in figure 9.

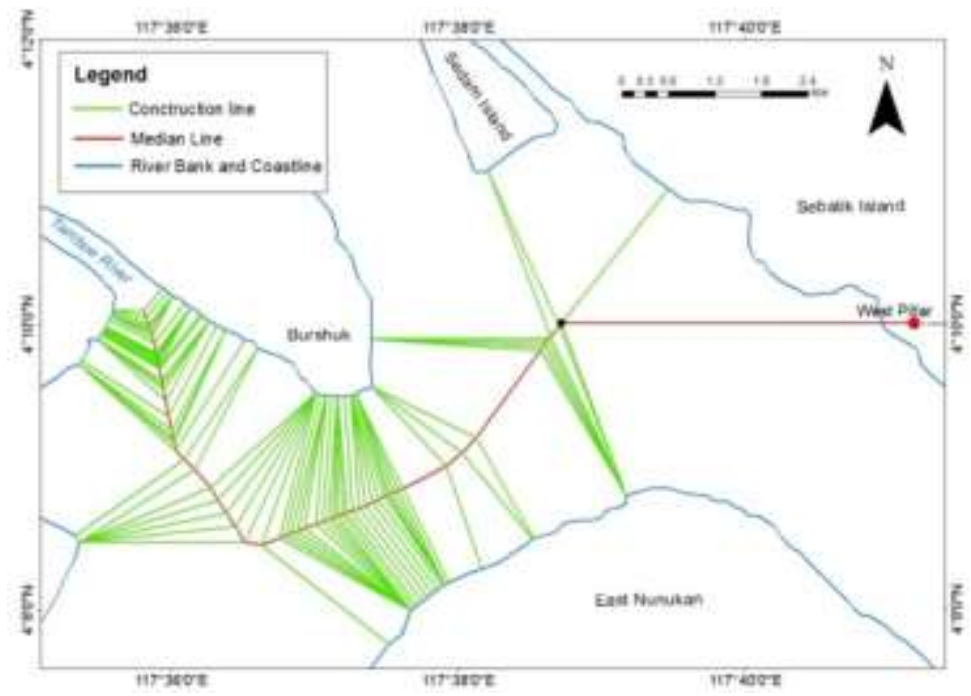

Figure 6. Median line and Construction line in segment 1

For segment 2, basic data used is the river bank that has been digitized from multitemporal satellite imagery so that later there will be several boundary versions based on satellite imagery years, 1989, 1999, 2009 and 2019. From the mouth of Tamboe the boundary line is continued up the middle of this river until it is intersected by a similar line running through the middle of Sikapal River; it then follows this line through Sikapal River as far as the point where the latter meets the watershed between the Sikapal hill (AA2 Pillar) and is connected finally with this watershed by a line taken perpendicular to the centre line of Sikapal River. The boundary lines and construction are shown in figure 10. 


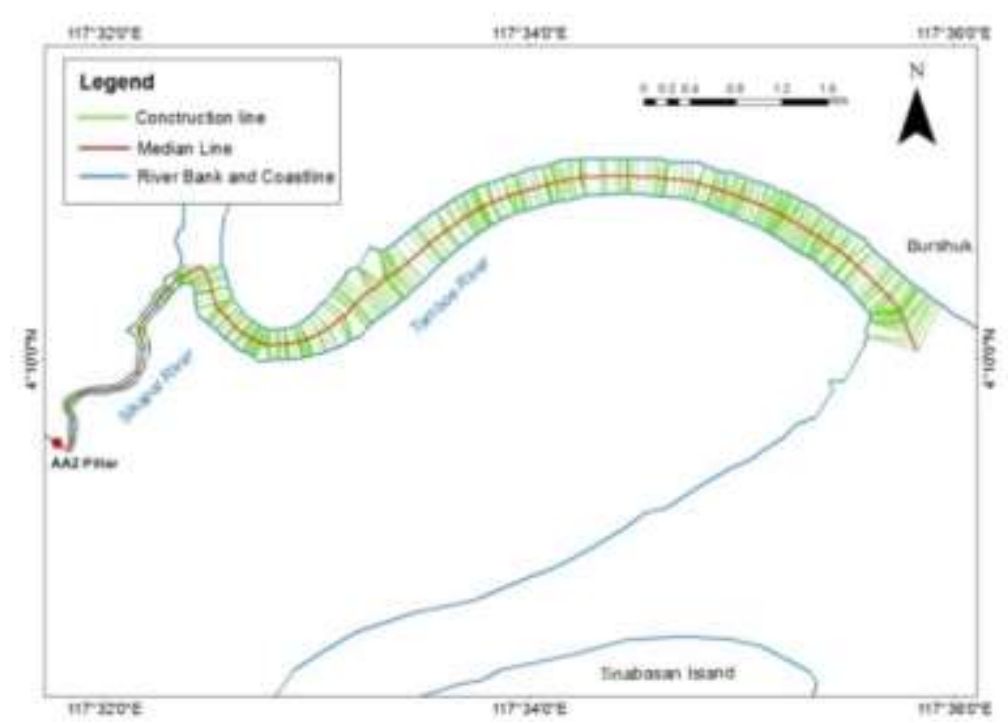

Figure 7. Median line and Construction line in Segment 2

\section{Considering Relevant Circumstances}

In this case there is Sedam Island, when viewed from the map of the Netherland-British Agreement in 1915 that the island has been drawn and until now the island still exists so the island is an influential factor. In addition, the length of the relevant coastline is also influential as shown in figure 11.

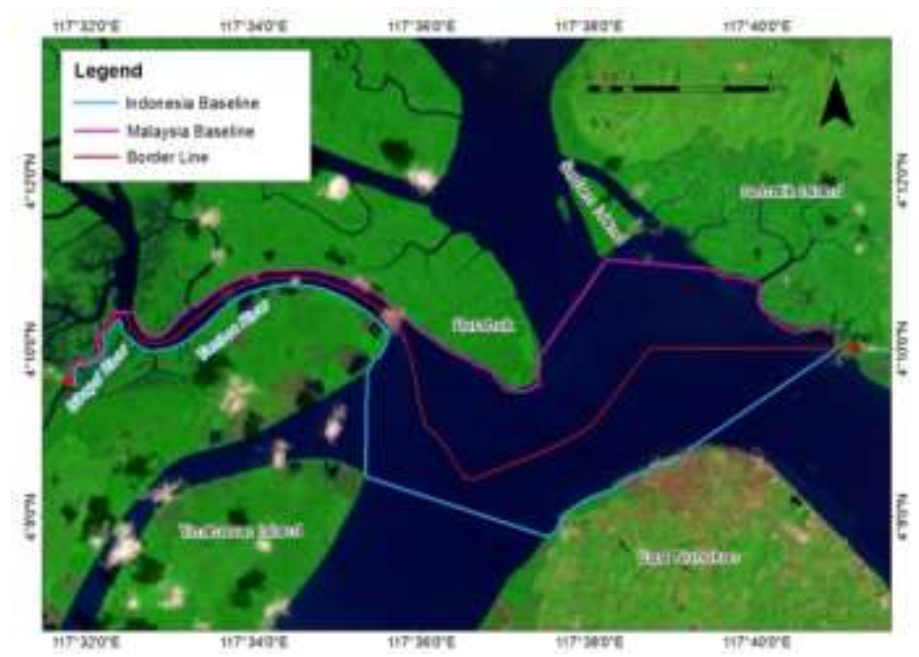

Figure 8. Relevant Coastline of Indonesia and Malaysia

\section{Disproportionality test}

Disproportionality test is done by comparing the length of the coastline and the area obtained between two countries to get the coastline and the area that is relevant for both countries. The disproportionality test results are listed in table 6 . 
Table 6. Disproportionality Test Results

\begin{tabular}{|c|c|c|c|c|}
\hline \multirow{3}{*}{ Years } & \multicolumn{4}{|c|}{ Comparison } \\
\hline & \multicolumn{2}{|c|}{ Relevant Coastline Length $(\mathrm{km})$} & \multicolumn{2}{|c|}{ Relevant Area (km2) } \\
\hline & Indonesia & Malaysia & Indonesia & Malaysia \\
\hline \multirow{2}{*}{1989} & 24.66 & 22.58 & 18.44 & 18.63 \\
\hline & 1.09 & 1 & 1 & 1.01 \\
\hline \multirow{2}{*}{1999} & 24.64 & 22.56 & 18.49 & 18.68 \\
\hline & 1.09 & 1 & 1 & 1.01 \\
\hline \multirow{2}{*}{2009} & 24.64 & 22.58 & 18.53 & 18.72 \\
\hline & 1.09 & 1 & 1 & 1.01 \\
\hline \multirow{2}{*}{2019} & 24.60 & 22.58 & 18.57 & 18.77 \\
\hline & 1.09 & 1 & 1 & 1.01 \\
\hline
\end{tabular}

Table 6 shows that Indonesia's relevant coastline is longer than Malaysia's relevant coastline in all years. Even so, the average length comparison of Indonesian and Malaysian relevant coastlines is 1.09: 1 in all years.

Unlike the length of the coastline, Indonesia's relevant area is smaller than Malaysia's relevant area. This means that in the median line for delimitating boundaries, the longer coastline does not mean the bigger area. The relevant area of Indonesia is smaller than the relevant area of Malaysia. The average ratio of relevant areas between Indonesia and Malaysia is 1: 1.01 in all years.

Same ratio at the relevant coastline length and relevant area due to differences in each are not significant. Therefore, median line drawn from data in 1989, 1999, 2009 and 2019 has suitable disproportionality test in producing equitable solution for border line between two countries.

\section{Comparative Analysis of Indonesian and Malaysian Boundaries Based on Basic Data Used}

From the process of delimitating median line in segment 2, different median line is obtained from the baseline data in 1989, 1999, 2009 and 2019. That is because constructing of median lines is influenced by different river banks. Then Median lines area overlaid by each other.

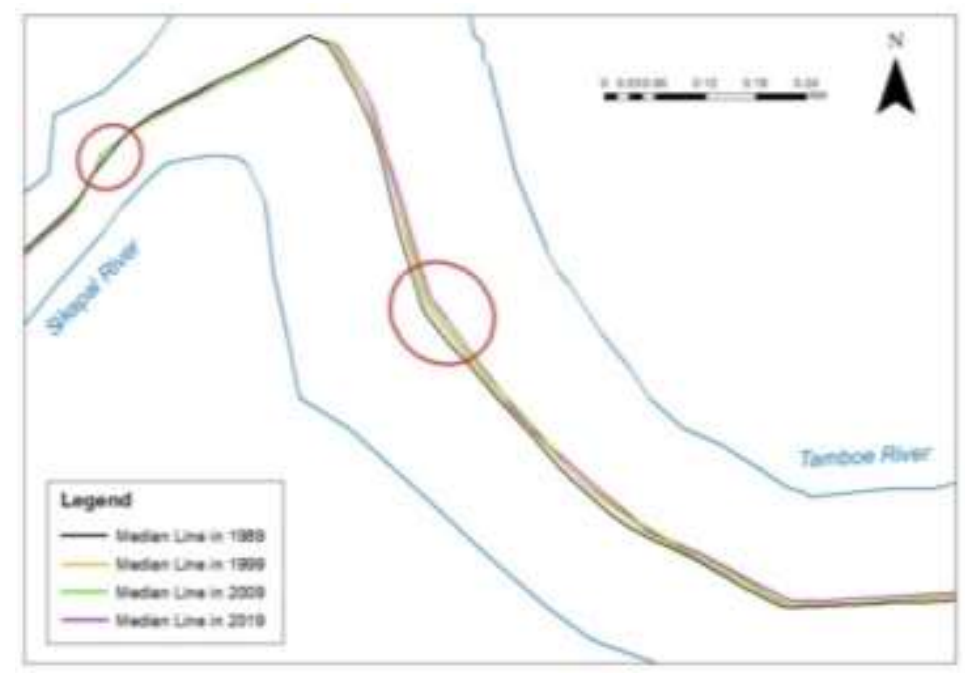

Figure 9. Median line Difference in 1989, 1999, 2009 and 2019 
In the westward curve of Tamboe River, the difference is in the 1989 Median line with the 2019 Median line where the 1989 Median line is more west than the 2019 Median line. Assuming the median line is Indonesia-Malaysia boundary line and the river bank used is the most recent (2019) so if using the 1989 Median line, Indonesian river area is smaller than Indonesian river area using the 2019 Median line. Whereas Malaysian river area is bigger using the 1989 Median line than the 2019 Median line is shown in figure 12.

The second difference is in the curve of the Sikapal River close to the estuary. The 2009 Median line looks more west than the other year median lines. This means that the Malaysian river area in 2009 is smaller than 1989, 1999 and 2009 but instead for the Indonesian river area.

Differences in some parts of median line cause differences in river area of both for Indonesia and Malaysia. The difference in segment $1+$ segment 2 has been shown in table 6 on the disproportionality test results. When divided per segment, segment 1 uses only one type of data namely Nautical Chart so that there is only one version of Median line whereas segment 2 uses some basic data so as to produce several versions of the river area shown in table 7.

Table 7 shows how different median lines in those years have affected the river area. The largest increasing of river area in 10 years is $0.05 \mathrm{~km} 2$ for Indonesia and $0.06 \mathrm{~km} 2$ for Malaysia, which is only $3.4 \%$ to $3.9 \%$ of the river area. The difference of area increasing of the river in Indonesia and Malaysia tends to be small. Therefore, the ratio of river area between Indonesia and Malaysia is same, which is 1: 1.03.

It has been previously analyzed that Annex Map of the 1915 Netherland-British Agreement cannot be used as a basic map to delimitate boundaries because of error position. However, the results of river area analysis for 30 years (intervals every 10 years) explain that the ratio of river area as the boundary of Indonesia and Malaysia is always same at 1: 1.03 which means increasing of river area is evenly distributed on the right side (Indonesia) and on the left side (Malaysia). Therefore, despite unavailability of spatial data showing the position of the river bank in 1915, it can be assumed that if median line is drawn on the river bank conditions at that time, then the river area of Indonesia and Malaysia will be calculated, then the area ratio will be the same.

It was concluded that what Netherland and British had agreed in 1915 for the river was proportional to the current conditions so that there was no concern of major changes in the boundary which was beneficial to either Indonesia or Malaysia.

Table 7. River Area Comparison of Indonesia and Malaysia in Segment 2

\begin{tabular}{ccccccc}
\hline \multirow{2}{*}{ Years } & \multicolumn{2}{c}{ River Area $\left(\mathrm{km}^{2}\right)$} & \multicolumn{2}{c}{ Area Increasing of The River $\left(\mathrm{km}^{2}\right)$} & \multicolumn{2}{c}{ Area Comparison } \\
\cline { 2 - 7 } & Indonesia & Malaysia & Indonesia & Malaysia & Indonesia & Malaysia \\
\hline 1989 & 1.40 & 1.44 & - & - & 1 & 1.03 \\
1999 & 1.45 & 1.50 & 0.05 & 0.06 & 1 & 1.03 \\
2009 & 1.49 & 1.54 & 0.04 & 0.04 & 1 & 1.03 \\
2019 & 1.53 & 1.58 & 0.04 & 0.04 & 1 & 1.03 \\
\hline
\end{tabular}

\section{Conclusion}

The maximum river bank shift over the past 30 years occurred in the river curves is 26.8 $\mathrm{m}$ on the left side of Sikapal River and $35.5 \mathrm{~m}$ on the right side of the Tamboe River. River banks shifting of Sikapal River and Tamboe River are relatively small with a maximum shift is $0.43 \mathrm{~m}$ to $1.18 \mathrm{~m}$ per year. This is because many mangroves grow around the river bank of the Sikapal River and Tamboe River which can hold back rate of erosion. The difference in the median line as border line affects Indonesian and Malaysian river areas. However, the 
difference is small, only $3.4 \%$ to $3.9 \%$ of the river area, so that the ratio of river areas of Indonesia and Malaysia is still same 1: 1.03 in 1989 to 2019. It can be concluded that rivers area of Indonesia and Malaysia when the 1915 of Netherland-British Agreement was proportional to the latest data in 2019.

\section{Acknowledgments}

We thank to the Geospatial Information Agency for support this research data and Saintek Progam from Ministry of Research and Technology for funded this research, for all the Researchers involved in it and also our deep appreciation to the reviewers of this paper.

\section{References}

Aher, S.P. et. al. (2012).'River Change Detection and Bank Erosion Identification using Topographical and Remote Sensing Data". International Journal of Applied Information Systems (IJAIS) - ISSN : 2249-0868. Foundation of Computer Science FCS, New York, USA. Volume 2- No.3, May 2012 - www.ijais.org

Arsana I. M. A. (2007). Batas Maritim antar Negara. Gadjah Mada University Press, Yogyakarta.

Arsyad. (2006). Konservasi Tanah dan Air. Bandung

Badan Informasi Geospasial. (2016). Digitasi Unsur Peta Dasar Validasi Peta Rencana Tata Ruang. Sekertariat BIG. Cibinong.

Badan Informasi Geospasial. (2019). Laporan Perundingan Common Border Datum Reference Frame (CBDRF) Indonesia-Malaysia Tahun 2019. Pusat Pemetaan Batas Wilayah. Bogor.

Dabojani, D. Mithun, D. Kanti, K.K. (2013). "River Change Detection and Bankline Erosion Recognition using Remote Sensing and GIS". Forum geografic. Volume XIII, Issue 1 (June 2014), pp. 12-17

Frevert, et. al. (1950). Soil and Water Conservation Engineering. John Wiley \& Sons, Inc. New York.

Hadi, S., Abidin, H.Z., Priyatna, K. (2015). "On Reliability of the Annex Map of the 1915 Land Boundary Treaty between Indonesia and Malaysia". FIG Working Week 2015 From the Wisdom of the Ages to the Challenges of the Modern World Sofia, Bulgaria, 17-21 May 2015

International Court of Justice. (2009). Maritime Delimitation in The Black Sea (Romania V. Ukraine). The Hague: International Court of Justice.

Jones, S. B. (1945). Boundary Making; A Handbook for Statesmen, Treaty Editors, and Boundary Commissioners. William S. Hein \& Co., Inc., Buffallo, New York.

Lillesand, T.M., Kiefer R.W., dan Chipman J.W. (2004). Remote Sensing And Image Interpretation. Fifth Edition. New York : John Wiley \& Sons.

Ngyuyen, L.D. et. al. (2010).”Analysis Of Changes In The River banks Of Mekong RiverVietnam By Using Multi-temporal Remote Sensing Data". International Archives of the Photogrammetry, Remote Sensing and Spatial Information Science, Volume XXXVIII, Part 8, Kyoto, Japan, 2010

Nurdin, Amin. (2015). Penentuan Opsi Garis Batas Negara Antara Indonesia dan Malaysia di Pantai Barat Pulau Sebatik, Terusan Tamboe dan Terusan Sikapal. Tesis Magister Teknik Geodesi dan Geomatika. Institut Teknologi Bandung. Bandung.

Prahasta, E. (2008). Remote Sensing Praktis Penginderaan Jauh \& Pengolahan Citra Dijital dengan Perangkat Lunak ER Mapper. Informatika. Bandung. 
Sosrodarsono, Suyono. (1983). Hidrologi untuk Pengairan. Pradnya Paramita, Jakarta.

Sukojo, B. M. (2012). Penginderaan Jauh (Dasar Teori \& Terapan). ITS-Press. Surabaya. 